HStud 27 (2013)2, 237-250

DOI: 10.1556/HStud.27.2013.2.3

\title{
CLERGYMEN BETWEEN THE CULTURES OF CHURCH AND VILLAGE: CONFLICT AND COOPERATION IN LATE MEDIEVAL HUNGARY
}

\author{
GABRIELLA ERDÉLYI \\ Institute of History, Research Centre for the Humanities, \\ Hungarian Academy of Sciences, Budapest, Hungary \\ E-mail: erdelyigb@gmail.com
}

\begin{abstract}
The paper aims to explore the scenario of lay-clerical conflicts and their negotiations by reading petitions of pardon handed in to the papal curia in the late fifteenth and early $16^{\text {th }}$ century from the Kingdom of Hungary. In course of the negotiation of violent conflicts, which very often entailed the killing of a priest, ordinary laymen and members of the rural pastoral clergy alike fabricated stories which they thought would best serve the forgiveness of their sins. However, as the paper argues, the act of petitioning to the papal curia in fact served other 'non-official' functions in the process of conflict negotiation. In the gaps of these short narratives we can detect that lay-clerical everyday disputes were in fact neighborhood conflicts deriving from their close co-existence.
\end{abstract}

Keywords: lay-clerical conflict resolutions, everyday life of the rural pastoral clergy, honor, language of insults

\begin{abstract}
Most Holy Father! Herman, the son of Martin, a layman from the diocese of Zagreb, the beloved son of Your Holiness humbly and respectfully related that he had, by devil inspirations, killed a priest and thus suffered the penalty of excommunication. Therefore he requests the Holy Father to absolve him from the above sentence and the sin of killing a priest together with his other sins.
\end{abstract}

Herman turned to the Apostolic Penitentiary from the Kingdom of Hungary with this petition in 1456. (The sources quoted below come from the Archivio Poenitentiaria Apostolica (Roma), Registra Matrimonialium et Diversorum, vols 1-745). Between 1450-1520, hundreds of laypersons asked papal absolution at this Roman office for killing a priest, and more than a hundred for commiting violence against clerics. By the $15^{\text {th }}$ century the Office of the Apostolic Penitentiary had become the chief and the cheapest route to both the salvation of souls and justice on earth in Renaissance Rome, handling violations of canon law ranging from irregular clerical ordinances and marriages to such heinous crimes as murder, sod- 
omy or sacrilege. Other papal offices, such as the Datary and Chancery, also dealt with similar affairs. However, the common man, peasants and lesser nobles from villages and market-towns as well as some burghers, rather tended to ask papal pardon at the Penitentiary, since the letters issued there were considerably cheaper (Salonen and Schmugge, 2009).

The primary aim of my study is to understand the local interests and relations behind the conflicts of the common men and their priests with the help of their petitions of pardon construed subsequently. The relationship of the laity and clergy is difficult to grasp, however, from the perspective of laymen, due to the brevity of their written reports, while the lengthier version of the events was most probably reported by them orally before curial judges. In contrast, the petitions of clergymen about committing or being involved in homicide cases, which rendered them officially inept to perform their priestly services and have a benefice, are not only numerous (373 petitions) but also fairly verbose. As a result, the clerical narratives, while busy with forging their own innocence and reporting in detail the events, are much more informative concerning the status of parish clergy in rural communities, which is our main concern.

The clerical narratives of homicide will be read here as representations of lay-clerical conflicts. What were the issues at stake? What were the strategies of conflict resolution? Why did the parties go to court? When they did, how did they represent the conflict and their enemies in public? And what kind of rhetoric tools served them in their efforts to justify their innocence? How was it possible at all to legitimate violence? The answers to these questions will bring us closer to understand how the common man perceived and dealt with social relations in general and what was the place attributed to and taken by local clergy, in particular.

While the crisis of the established Church served to account for the protestant reformation, violence against the clergy in the late middle ages seemed evident: lay discontent with the negligent, immoral and parasite clergy developed into general anticlerical sentiments, which manifested in violent acts against priests. More recent accounts of the protestant reformation are varied, but unanimously argue the opposite: the reformation rooted in a rich and diverse religious culture based on regular lay engagement in the spiritual and devotional services (baptism, marriage, funeral, holy mass, processions) offered by the established Church, which makes it more difficult to account for lay-clerical conflicts (Dixon, 2011, 34-43). As the argument goes, lay-clerical relations were primarily constituted by the laity's expectation that the clergy should mediate effectively between the other and this world by delivering the sacraments. Lay-clerical rivalry over the access to the sacred could have given rise to occasional conflicts, since laymen tried to bypass clerical control by developing independent religious practices such as the use of sacramentals, pilgrimages and the veneration of local saints and relics, which the clergy often labelled as superstitious (Scribner, 1987, 32-41). It is generally ar- 
gued, furthermore, that under the impact of the protestant reformation, lay-clerical relations, which in the late middle ages were primarily structured by the clergy's mediating function, substantially transformed. The medieval differentiation between the clergy and laity disappeared under the impact of Lutheran teachings such as the priesthood of all believers and justification by faith, which deprived the clergy of its mediating role. As a result, the argument follows, the laity turned to the clergy with a new set of expectations based on more secularized values: they considered the local pastor as a model person, as an exemplary husband and father and an honest member of the community fulfilling his duties also in his profession (Dixon and Schorn-Schütte, 2003, 1-38).

In contrast, by conjecturing the common people as active agents instead of passive subjects blindly following abstract ideas, I will explore those situations when the relationship of late medieval villagers and their priests was rather shaped by secular values and social relations. I will direct the attention to the moments when they played similar roles and had shared experiences, and consequently argue that late medieval pastoral clergy lived in close co-existence with the laity. The killing of priests, and in general, violent lay-clerical conflicts represent, as will be suggested, not the difference and opposition of clergy and laity, but rather their similarities and interdependence. The analysis of stories about violent lay-clerical conflicts is intended to highlight some of the - from further away - invisible dimensions of this close co-existence at the end of the middle ages.

\section{Parish Priests as Members of Local Communities}

We meet parish priests in their own petitions playing social roles similar to those of their parishioners: when they are not mediating the sacred or represent the legal authority of the church, but they are relatives or neighbors, and consequently, friends or enemies in the eye of the village community. Their conflicts with laymen seem to derive primarily from family- and neigbourhood relations and turn around the issue of honor.

First of all, they appear as pater familias taking care of the safety, prosperity and morals of their households. A parish priest usually lived together with an elderly or a 'girl' female relative in charge of housekeeping. Moreover, the parish priest usually tutored his nephew(s) for the priesthood, kept a chaplain who helped in performing religious liturgies and had some servants in the household. The pastor enters the scene as an authoritative and responsible patriarch imposing punishments "in accordance with the committed crime" on "impertinent", "irreverent" and "badly behaving" matrons and nephews.

The story of the parish priest of Siófok also attests to such a conflict within the household. He mentions only incidentally that the servant whom he insulted and 
beat on their way home in the night, a year earlier battered his adopted father. Adapting his story to official expectations, he did not explain his reasons for insulting his servant, but rather went into the details of the road brawl which finally ended with the death of the servant. Only a close reading of his story makes it possible to notice that, in fact, he retaliated an earlier insult premeditatedly, which he, however, for the sake of granting absolution, tried to depict as an occasional quarrel that was triggered by his irresponsible behaviour due to his drunkenness and ended with his killing the servant out of self-defence. Therefore we can rightly suppose that the physical clashes demanding the life of priests were also the episodes of long-standing disputes between families and neighbors. As we can learn also only by chance from the story of Miklós, son of Mátyás, that the priest, whom he had killed, was in fact his brother.

Besides safeguarding order and morals within the household, the patriarch was also responsible for the well-being and safety of household members within the local network of relationships. Pál Albi, the parish priest of the Saxon village of Schattendorf, gave one of his female servants, endowed with a respectable dowry, as wife to a male servant. After a while, however, the husband started to beat his wife and when, one day, he even tried to kill her, as the parish priest related the events, the desperate wife took refuge in the priest's house. Since the husband continued to trouble his wife, the priest Pál could not bear it with "a peaceful soul" and one night he sneaked into the man's house and stabbed him in bed. The story reflects beside the parish priest's responsibility for the members of his household that anti-violent behaviour served as an effective argument, falling in line with expectations, in the process of receiving papal grace.

Parish priests continued to farm lands, and dealt severely with negligent servants wasting wealth and with neighbors caused some damages. The priest Ambrus Cserepes lost his temper and beat the pastor who, notwithstanding his earlier warnings, continued to graze his cattle in his garden. Pál Horvát was even ready to ride out daily to his lands in order to defend springing crops from alien cattles strolling over.

The stories reporting violent acts (beatings, woundings, mutilations) against clergy only exceptionally reveal that the anger was not directed against the priest's person, but rather against his family. Mátyás Menecsics, for example, briefly mentioned that the layman who cut off a piece of his finger was an enemy of his brother. What has seemed to be a lay-clerical conflict also turns out to be a single episode in a long-standing family feud in cases of assaults against the parsonage. House-raids were the most common acts of "rightfully" avenging by force an earlier offence. The enmity is signaled in the stories by the workings of hatred (odium). "Gergely Pap, a priest from the village Orbányosfalva related that a layman called Demetrius nurtured such a tremendous anger against him and his servant that he regularly threatened to kill them. One day Dénes came to his house 
and impudently killed his servant while he was absent". Informed about the homicide, the priest Gergely set off for home accompanied by some of his friends, and in such an upset state of mind he ran into Dénes, who, "being overcome by anger" (furore repletus), started to chase him with a sword and an axe in his hands. Gergely could only be saved from death with the help of his friends, who battered Dénes "according to Hungarian ways" (hungarico more) so severly that he died six weeks later.

Considering the social integration of laity and local clergy, it is not suprising that they spent together their leisure time, which, in contrast to postindustrial societies, was not yet separated from the time designated for work (Thompson, 1967). Their common leisure, however, often supplied additional occasions for debates and brawls. Priests and laymen appeared together in groups on the roads not only when heading for markets, but also for buying wine. This kind of "wine-tourism" served both the uploading of empty barrels at home and the entertainment of common wine-tasting, too. The priest János from Szalatnok also joined to the people leaving from Vidóc, a little village in Slavonia for a nearby village. They were on their way home, in other words, after having consumed a good amount of wine, when a man started to hit in jest the parish priest with a rod, which he responded by playful counter attack. The game, however, ended with the man's death, whose bleeding knee had got bitten by a dog.

Even in face of the prohibitions of its superiors, formulated in synodal decretals, the local clergy casually participated in tavern drinkings. They did not feel necessary to apologize for visiting taverns even afterwards, just as laymen considered it natural to invite local clergymen for private dinners. One evening, the cleric Pál from Szepetk entered a tavern together with his parish priest "where they spoke and drank together with laymen in an honorable manner" - this was the usual way of setting the scene of joyful gatherings that often turned into verbal and physical conflicts. Pál's story went on: the laymen who arrived later gathered at a nearby table and when they were already totally drunk, one of them threw a roast goose over to their table, but yet discontent with such an insult attacked the parish priest and his company with a naked sword.

The local clergy not only shared casually the happy hours in the taverns, but did not find anyting wrong either in the popular games and gatherings following religious rituals and festivities, in which they also participated. The priest Ambrus, after performing the funeral ceremonies, joined with his chaplains the villagers' feast "celebrated with abundant eating and drinking according to local customs". In a village in southern Hungary, after the parish priest and the parishioners had celebrated a mass offered for the Virgin Mary so that she would free them from the plague devastating the region, they joined in a great convivial evening. Blasius priest participated together with his kin, although - as he wrote in his petition - he left earlier, asking the permission of his fellowmen. 
As sacred and profane rituals intermingled, so did priests and laymen join in one company not only at the table of great village festivities tied to cyclical festivals but during family occasions, too. Márton, the parish priest of Mecske, a tiny village in southern Hungary, was invited for a wedding in a nearby village. As he went together with his parishioners on the road, in the outskirts of the village, a young mate approached him and asked him to lend him his horse. Unmarried youth "were building hedges as was the custom of the region" and organized a tournament of horse-jumping. The parish priest must have had a very good horse, since everyone wanted to ride it once they had seen it.

As reflected by the above situations and stories, rural parish priests were local boys rather than outsiders. Even at first glance, they looked like their parishioners: they also had a beard, traveled on horseback, and wore a sword untroubled by church prohibitions. At the level of social practices, the similarity extended further: they also inherited family property, ran a household which provided for their relatives, were tied with affinity and consanguinity to the village community, they continued to be farmers, drank together with parishioners in the local tavern, and participated in local feuds and brawls. All this was partly due to the fact that they usually came from the same social groups they served. Village priests were typically the sons of peasants, who were tutored by village priests and schoolmasters either in their own village or further away. Even if they went to study to other regions, they seem to have returned to their village of origin, therefore being finally natives to the regions they served (Erdélyi, 2011).

\section{The Hidden Script of Lay-Clerical Conflicts}

Interestingly, the varied but always very concrete causes of feuds surfaced in a symbolic language in course of the verbal battles. Even in the tavern, people decribed their clerical enemies as bad priest rather than as their malicious neighbors. The personal enemy thus appeared as a priest abusing local expectations or failing to fulfil his clerical duties, which injured communal interests, and consequently, could be debated also in front of public authorities. At court, the pecularities of neighborhood conflicts, loaded with individual interests and emotions, were translated into the universal issue of priestly honor comprehensible for the general public (Burghartz, 1989). Priestly honor, similarly to female honor, revolved primarily around sexual virtue (Gowing, 1996, 111-38). The sexual abuses of wives threatened the honor of their husbands just as the illicit relationships of priests Swanson, 1999, 163-4).

The script of verbal fights is easily readable in the petition of Imre Corcunctal, a cleric serving the parish priest of the St Jacob church in the village Majsa in Tolna County. A layman called Balázs "falsely denunciated him" (fornicatione ... 
calumpnose accusavit), as he claimed, for fornication first at the landlord's tribunal and later before the parish priest. Unsurprisingly, Balázs is displayed by Imre as "a perverse man of ill repute" (perversus vir et male fame), who behaved aggressively with Imre. The charges against Emericus however fell flat, both the landlord and the parish priest recognized, as Imre contended, his "innocence" and the "malevolent intrigues" of his enemy, who, however, denied at court to make peace and ask sorry for the defamation. At this point, it seems, the efforts of the man to defeat his priest-enemy with the support of legal autorities, came to nought.

Finally, one night, as Imre continued, on his way home, Balázs assaulted him with insults and threatenings, to which he responded something like 'Blasius, I have had enough of your defamations, be considerate of Christ's passion and leave me in peace'. Blasius, bursting into diabolic anger, replied: 'Rascal and son of a bitch, I have recently failed to ravage you, but today I'll drag you out of your house, spoil you, drink over your tunic and pass my sword through you.'

The battle of words, performed in the language of honor, developed into a fist fight, leaving the priest on top and the actual reasons of their hostility unveiled. Not his mother's, but his own alleged sexual misconduct served as an insult against the priest Mátyás: "Pastor, give us your concubine!" - shouted his enemy while trying to open the front door of the parsonage. When Mátyás himself opened the door, his enemy continued: "You'll see now what you deserve: you will have to die shamefully!" Yet, during the ensuing row described at great length no woman hidden in the house appears on the scene.

In a case from the village Toplica (Zagreb County) the actual motivations for damaging priestly reputation come to the surface exceptionally due to the lucky circumstance that not only one, but two of the participants tried to present an acceptable story about the same events before the papal office. Pál from Worsck, the priest of the Holy Trinity parish church fabricated a homicide story, in which the conflict lay between two of his parishioners, Mihály Borbély ('Barber') and Péter Varga ('Cobbler'), on the one side, with his chaplain, Lukács Scopzich, on the other. The laymen accused the chaplain with adultery, in other words by seducing a married woman. The parish priest tried to mediate and make peace between the parties, but his reprehensions were enough only to draw upon himself the anger of Mihály Borbély. In his version the conflict reached its climax when Borbély unexpectedly killed his fellowman, Péter Varga. This outcome is totally incomprehensible: why did the two men turn against each other when it seemed that they got into trouble with the sexually abusive chaplain? We learn from Lucas chaplain's story, handed in to the Penitentiary the same day, December 13, 1487, that he had 
only been a minor character in the conflict of the two laymen: the two neighbors engaged in a dispute over something, during which both men called the other's wife the chaplain's lover. Most probably the neighborhood conflict developed over a certain kind of material damage, as it was most often the case, but this went unnoticed while they debated publicly the virtues of their wives. We know nothing about the final settlement of the conflict and the fate of Mihály Borbély who shot to death his neighbor by an arrow, since he did not ask for papal pardon. The two priests entangled in the neighbors' affair, however, needed the pope's letter declaring their innocence. The parish priest, whose mediation came short, felt himself responsible for the death of one of his parishioners. No surprise, as priests traditionally were expected to be the promoters of peace within the parish (Castan, 1983, 239). Although he played only a secondary role, he presented himself as the protagonist in his story, distorting, as a result, the laymen's conflict into a lay-clerical antagonism. His version must have seemed though credible at the Roman office, where stories about laymen killing priests were handled in daily routine.

As we have seen, the honor of priests, which turned around their sexual virtues, served as a tool to discuss in public - either in the tavern or at court - neighborhood conflicts. When such an attack on honor brought no success, and the use of violence seemed more effective, the language of the ongoing battle shifted from priestly to worldly honor. Rival parties called their personal enemies "rogues" and "rascals", which served to legitimate violent self-help (Tringli, 1998, 19). Following this script, the cleric György Rojcsai also criminalized his enemy:

\begin{abstract}
for the sake of leisure he visited once a house, where many had gathered already. After talking for a while, a man, who had attacked already a cleric that day and committed several homicides ..., turned against him by quarelling and insulting words. He called him and his parents thieves and rogues and therefore unworthy of the company of virtuous men. He responded to the insult: 'neither me nor my parents have ever been thieves or rogues, and I ask you in the name of God to leave me in peace, since I have nothing to do with you, neither good nor bad'.
\end{abstract}

Soon afterwards, swords and knives were taken in hands.

Clergymen preferred to call their lay enemies murderers and describe them as stubbornly hostile and aggressive toward priests. Balázs Zámbó, a priest from the diocese of Győr in western Hungary shared a dinner in a big company in the house of Mihály Babos, when Miklós Német ('German'), who arrived later, started to insult him "out of envy". "Since the priest Balázs has already heard Mihály confessing to have beaten a priest, he tried to calm him very kindly, saying 'my dear friend, do not speak like that'." His kindness, however, only higthened the spirits of Miklós, who, in response, sought to damage his enemy's priestly reputation: 
"in fact, he even has a son" - he claimed suddenly. This was the moment when the parties, according to the usual script, took in hand rods and axes, and the slanderer lay dead on the floor soon afterwards.

Both the verbal assault on priestly honor in the courtroom and the criminalization of priests in moments of violent self-help were episodes in the process of conflict negotiation, which most often ended with peacemaking (Smail, 2003). Nicholaus cleric was denunciated, as he claimed in his petition, unjustified by a man called Mayus. As the phrase he uses (apud banos et gentes diffamasset de quodam crimine) suggests, he was probably proscribed by the county assembly as a malefactor, who could be killed by anyone. Miklós got so scared, he says to have been at a loss, having no idea what to do, since the more he implored his enemy to stop slandering him, the more desperately he vexed him. Unable to bear this further, he ordered his men to tear out his enemy's tongue. In fact, they cut off only a little peace, and as Miklós claims, his enemy has recovered quickly, but was afterwards killed by others "due to his bad tongue" (propter malam suam linguam). In his petition he argued emphatically that his enemy made peace with him before his death (ante tamen mortem cum dicto exponente in plena concordia amicitie remansit). While the conflict evolved, the concrete reasons of which remain again unclear, one of the parties sought redress in public, the other used sheer violence. This suggests that the use of courts and the use of violence were varied strategies within the process of conflict negotiation. Violence was not considered as an act of brutality, but similarly to litigation, it was a meaningful social practice serving to overcome an enemy or pushing him towards concord - which was also the outcome of the hostility between Miklós and Mayus.

The identical functions of self-help and actions at law is suggested by the rivalry for the parsonage of the village Belesz in southern Hungary. The parishioners expelled from the parsonage the parish priest, János Csonka ('Maimed') due to his negligency and long absences, and invited György Vágó in his place. The thrown-out parish priest sought redress by denunciating his heir in the parsonage at the diocesan court. As a result, the priest György tried to cut short a long lawsuit by offering an agreement out of court, which was accomplished with the mediation of arbiters. János, however, broke the contract: he decided to demand extra money from his heir. Considering the erratic nature of his enemy, yet it seemed to György more effective to pursue the hostility at court: he denunciated János to the vice-archdeacon's tribunal. On his way home, however, he ran into János and his brother, Antal, whom he told - out of mischief - that he had just initiated a procedure against János. He did not have the slightest chance to regret this: the two men got so enraged by such news that they responded by force, which Georgius did not survive.

If one went to court, thus publicized the enmity, which could have served, however, varied ends and entailed different interpretations depending on the particu- 
larities of the situation and the participants. In the above case of Mayus, the publicizing exacerbated the conflict, since the denunciated party interpreted it as an act of revenge and his public humiliation, which instigated him to behave violently afterwards. Since in customary law, unjustified slander was punished by the tear out of the tongue (Csukovits, 2005, 217), he, by assuming the role of authorities, committed legitimate violence. Denunciation to courts based on unjustified slanders were not the least interpreted by contemporaries as "more civilized" or "more rational" than acts of physical violence. It was only another field of social competition, performed not by swords but the - both financially and psychically more burdensome - armory of legal expertise (Kagan, 1981, 161). In the first phase of the affair of the two priests, the initiation of the lawsuit urged parties to reach a private agreement. Later on, however, since to the hot-blooded János priest such a battle in the courtroom seemed harmful and dangerous, it prompted him to commit violent self-help.

As suggested by the above stories, people did not expect from courts to settle their conflicts, neither did they consider litigation a more acceptable or friendly way of conflict-settlement. They entered the courtroom as another field of social competition, where their honor and reputation was at stake. Thus, they only entered when it offered their advancement, and evaded if seemed to their detriment.

As we have seen, people tried to display their personal enemies as criminals, who behaved aggressively "without any sound reason". As another story-telling strategy, they represented their own violent acts as legitimate. The argument supporting it was most often self-defence. This suggests that they adapted their stories to official expectations, which distinguished between purposeful violence, which was generally outlawed, and self-defence, which, if proven, went unpunished. Moreover, in the process of constructing their own innocence, they strove to define their own emotions as legitimate anger due to some earlier damages they had suffered, while their enemies were claimed to have been motivated by malignant hatred. Put otherwise, they followed a different logic, which differentiated not purposeful and casual, but legitimate and illegitimate violence. Besides, actions, as they perceived, directly followed from emotions. They could not imagine any human action independent of emotions. As we have seen, for Pál Albi, the parish priest of Zalatna it seemed a perfect justification to say that he could not bear anymore with a "peaceful soul" the vexations of the man he killed.

The stories fabricated about the killing of priests also reflect the workings of intense emotions. Some of the petitioners asked for curial confessors to absolve them instead of the local bishop, since "in fear of death they do not dare to return to the presence of the bishop and the place of the committed crime". In other words, after the events they were so scared that they ran as far as Rome. But what were they afraid of? Most probably they dreaded the imminent revenge of the kin and friends of their victims. They could have been also afraid of the death penalty, 
which was the official punishment of homicide. This was however more easy to evade than the wrath of enemies. Death penalties were rarely executed, since in practice hostilities rather ended by peacemaking procedures and the payment of fines (homagium) (Tringli, 2007).

The killing of a priest was also punished spiritually: the sentence of excommunication, which ensued automatically, could be absolved only by the pope in these cases. The rite of absolution included the public penance of sinners on the spot, which was meant to serve the prevention of crimes: the sinner requested for himself a penance that, as the established formula goes, served "his own salvation and the deterrence of others". Besides averting divine anger, however, the wrath of the offended party also needed to be handled. Since violent crimes against the clergy fell under ecclesiastical jurisdiction, the relations of the victim could turn to the diocesan vicar's tribunal. In course of the ensuing legal procedure the parties usually reached an agreement, which included the payment of fines. In this context, it seems probable that those sinners ran to Rome, for whom the usual script of peacemaking was not a possible solution and they rather reckoned better to disappear for a while. From this perspective, the petitioning to the Roman office served to suspend the enmity and to avert the vengeance of their outraged enemies.

Irrespectively of legal norms, men and women embedded in the local network of relationships were seldom sentenced to death. More precisely, even if the court passed a capital sentence, instead of its execution, it functioned as a stage in a process heading, as generally expected, towards the peacemaking of hostile parties. The situation was very different for those, however, who were outsiders in the community which arrested them. Robbers and highwaymen with no ties to local communities had a good chance to end on the gallows. The notaries and judges of the Penitentiary regularly met with dramatic stories about such executions. Clerics robbed and wounded on the road, in their petitions tried to explain how they were forced by the villagers or townspeople, who arrested and sentenced to death their assaulters, to take an active part in the hanging. In a world of social reciprocities, only the offended party could initiate a suit, and when he was himself an outsider to the community that took action against his robber, he was also expected to participate in performing the punishment (Mezey, 2007, 357-8). Clerics placing the knot on robbers' necks were thus pushed to play the extremely profane role of hangmen, having a difficult time to justify it before ecclesiastical authorities afterwards.

Lőrinc Nádasdy knew the ins and outs of dramatic story-telling. He was galloping alone in deep snow across the woods - he writes, provoking immediately the sympathy and anxiety of the reader - when highwaymen assaulted him, took away his cloths, horse and money, cut off one of his ears and tied him to a tree. He was just about to freeze to death when out of God's mercy he escaped. This was how- 
ever not the last twist of his story: when he reached the nearest village, he witnessed the following:

\begin{abstract}
One of the robbers, sitting on his horse and wearing his cloths, was just presented by the village judge, who asked him: 'Whose cloths and money are these?' The robber turned towards the cleric Lörinc and replied: 'They belong to that priest.' The judge again: 'And to whom belongs the horse?', 'To the same priest.' - answered the robber. 'And who cut his ear off?' - interrogated further the judge. 'I did.'
\end{abstract}

After the robber had thus confessed everything, Lörinc, as the person offended, was forced to hang him. We are even able to imagine vividly the tension that vibrated in the crowd gathered to watch the execution. "After having escorted the robber to the scaffold, the robber said: 'I ask you by the love of God not to hang me, just ascend and tie the knot to the column and then leave. I have sinned against you, still I beg you to intervene for me by God'." Lörinc then ascended the stairs, tied the knot and left him. "The robber meanwhile begged to the crowd to pray for him, after which he jumped off the stairs and died." Although priests were officially expected to refrain from all forms of violence, let alone execution of criminals, neither laymen nor possibly clerics, even if they apologized thus subsequently, were a bit concerned about this.

\title{
Conclusions
}

Ordinary people perceived and registered that their priests differed from them in certain ways. Miklós Babos, who started to insult Balázs Zámbó priest, "was scorned by the inn-keeper in a friendly manner that he should not speak about a priest with such words", and his fellow-taverners "also told him off for speaking with such a disrespect with a priest". The special attitude towards priests was connected to their role as mediators between this world and the sacred realm. People needed their services, they expected their priests to absolve them from their sins and deliver the sacraments, whose transcendent powers were believed to have a direct influence also on this-worldly affairs.

Nonetheless their role as mediators, the local clergy, and especially rural parish priests continued to control large household and farm lands, and were socially integrated - by kinship, affinity and friendship - into local communities. They spent together their leisure time with their parishioners. Their everyday disputes were neighborhood conflicts and tavern brawls, deriving from their close co-existence. Since they were embedded in the local network of reciprocal relationships, they applied the same tools of conflict negotiation as their parishioners did. They used 
violent self-help or went to court to their own advantage. The clergy also used the same language, reflecting their similar way of thinking, when they had to account for their conduct in course of evolving enmities: they argued to have committed violence legitimately since it followed from their emotions, hatred or love. But their enmities with laymen, according to the accepted script, most often ended with peacemaking. Priest-killings occasionally occurred yet when peacemaking procedures for some reason broke down.

It comes as no surprise, therefore, that in their everyday practices people set the same norms to their priests. They expected them to be friendly neighbors, honest farmers, responsible household heads in terms of duties, and cheerful companions when it came to leisure. When the priest Lörinc Baktani visited his mother and sister in his village of origin, the dinner consumed in high spirits ended in bloodshed: his brother-in-law invited him to continue drinking together in the night, he, however, would have preferred to go to sleep considering his duty of celebrating mass in the next morning.

The contradictions inherent in lay expectations towards the clergy derived from the duality of their sacred and social-secular roles. The complexity of their status is also reflected by the language of insults, which targeted either their priestly or their wordly honor. Playing a variety of sacred and profane roles from hangmen to the minister of the Eucharist, they had a difficult time in fulfilling both ecclesiastical and lay expectations. Although they also had family, a household and a farm, their structure differed from those of their parishioners. The differences between a house-maid and a wife, a niece and a son, as well as their exemption from taxes in contrast to the serf-plots, their moderate drinking as opposed to drunkenness were ever lurking behind apparent similarities.

\section{Acknowledgements}

My researches concerning the Apostolic Penitentiary are supported by the National Foundation for Scientific Research in Hungary (Országos Tudományos Kutatási Alap/OTKA-81435). I am also grateful for the Bolyai Scholarship of the Hungarian Academy of Sciences for their generous support.

\section{References}

Burghartz, Susanna, 1989. Disziplinierung oder Konfliktregelung? Zur Funktion städtischer Gerichte im Spätmittelalter: Das Züricher Ratsgericht. Zeitschrift für Historische Forschung, $16,385-408$. 
Castan, Nicole, 1983. The Arbitration of Disputes under the 'Ancien Regime'. In: John Bossy, ed. Disputes and Settlements: Law and Human Relations in the West. Cambridge: Cambridge University Press, 229-60.

Csukovits, Enikő, 2005. Bün és büntetés a középkori városi gyakorlatban [Crime and Punishment in Medieval Towns]. In: E. Csukovits and T. Lengyel, ed. Bártfától Pozsonyig. Városok a 13-17. században [From Bardejov to Bratislava. Towns in the 13-17 $7^{\text {th }}$ Centuries]. Budapest: MTA TTI, 199-222.

Dixon, C. Scott and Schorn-Schütte, Luise, 2003. The Protestant Clergy of Early Modern Europe. In: Dixon and Schorn-Schütte, ed. The Protestant Clergy. New York: Palgrave Macmillan, $1-38$.

Dixon, C. Scott, 2011. Contesting the Reformation. Oxford: Wiley-Blackwell.

Erdélyi, Gabriella, 2011. Szökött szerzetesek. Eröszak és fiatalok a késö középkorban [Runaway Friars. Violence and Youth in the Late Middle Ages]. Budapest: Libri.

Gowing, Laura, 1996. Domestic Dangers. Women, Words, and Sex in Early Modern London. Oxford: Clarendon Press, 111-38.

Kagan, Richard L., 1981, Lawsuits and Litigants in Castile, 1500-1700. Chapel Hill: University of North Carolina Press.

Mezey, Barna, ed., 2007. Magyar jogtörténet [A History of Hungarian Law], Budapest: Osiris.

Salonen, Kirsi and Schmugge, Ludwig, 2009. A Sip from the "Well of Grace": Medieval Texts from the Apostolic Penitentiary. Washington: The Catholic University of America Press.

Scribner, Robert W., 1987. Ritual and Popular Religion in Catholic Germany at the Time of the Reformation. In: Robert Scribner, Popular Culture and Popular Movements in Reformation Germany. London: Hambledon Press, 32-41.

Smail, Daniel Lord, 2003. The Consumption of Justice: Emotions, Publicity, and Legal Culture in Marseille, 1264-1423. Ithaca, N.Y. and London: Cornell University Press.

Swanson, Robert N., 1999. Angels Incarnate: Clergy and Masculinity from Gregorian Reform to Reformation. In: D. M. Hadley, ed. Masculinity in Medieval Europe. Harlow: Longman, 163-4.

Thompson, Edward P., 1967. Time, Work-discipline and Industrial Capitalism. Past and Present, 38 (1), 56-97.

Tringli, István, 1998. Jagelló-kori levelesítő jegyzék Zalából [A List of Proscribed Criminals from the County of Zala in the Jagiello-era]. Levéltári Közlemények, 69, 3-30.

Tringli, István, 2007. Fehde und Gewalttätigkeit. Vergleichen eines germanischen und ungarischen Rechtsinstituts. In: E. Balogh, A. Hegedüs, and P. Mezei, ed. Legal Transitions. Development of Law in Formerly Socialist States and the Challenges of the European Union. Szeged: Pólay Elemér Alapítvány, 281-6. 